\title{
The ripple effects of a partisan, free newspaper: Israel Hayom as disruptive media actor
}

\author{
Michael Dahan*, Sapir College, Public Policy and Administration and the School of Communication \\ Mouli Bentman, The Hebrew University of Jerusalem Political Science AND Sapir College, Public \\ Policy and Administration
}

${ }^{*}$ Corresponding author: dahanm@gmail.com

\begin{abstract}
During its 10 years of existence, the free newspaper Israel Hayom (Israel today) has come to play a pivotal role in Israeli national politics and to serve as what we define as a disruptive media actor among other, commercial, daily newspapers in Israel. The seemingly innocuous daily newspaper, founded in 2007 and distributed widely, has, since 2011, become the most widely read newspaper in Israel. We suggest that Israel Hayom be viewed as a "disruptive" actor in the areas of politics and the media in Israel. Adapted from Christensen's (1997) concept of disruptive technology or innovation, we define as disruptive a media actor that significantly impacts the field of politics and media economy, essentially forcing a change, or changes, in the "rules of the game". While this model is currently unique to Israel, it is likely that under similar conditions further cases shall present themselves in the future.
\end{abstract}

Keywords

Israel Hayom, Israel, free newspaper, disruptive media actor, democracy

\begin{abstract}
"Men, such as they are, very naturally seek money or power; and power because it is as good as money." Ralph Waldo Emerson, 1837
\end{abstract}

\section{Introduction}

Over the last 20 years, free newspapers have played a crucial and important role in relation to the printed press, challenging existing press models and breathing life into a troubled sector. In an era where print media is struggling to survive, the free press helped expand newspaper distribution in general. The primary business model: a "slim" editorial board with few reporters, generally fewer pages, articles drawn largely from press agency reports and the international press, with profit generated by heavy advertising within the widely distributed newspapers in major cities and public transportation depots. For a while this model proved to be quite successful, serving as a source of hope for print journalism, in terms of a new and viable model - at least until the financial cri- sis of 2008, which led to a dramatic drop in the distribution of free newspapers along with the closure of many (Bakker, 2013). As Bakker notes

"Free newspapers seem to follow a typical life
cycle pattern, moving from growth to maturi-
ty, and to saturation and decline." (ibid, p. 1)

In this paper we present an alternative model of free newspapers which has enjoyed success in Israel. Israel Hayom (owned and controlled by American billionaire Sheldon Adelson) is not only a free newspaper with the widest distribution of any newspaper in Israel; it is also a free newspaper that operates against all the defining and common characteristics of free newspapers. As opposed to the "slim" editorial board of a typical free newspaper, Israel Hayom has a professional and 
well staffed editorial board, employs professional and senior journalists, is a full length tabloid newspaper with a weekend edition and weekend magazine, and it has operated at a continued financial loss since its inception in 2007. Rather than trying to justify its financial and commercial existence, the paper seems to do quite the opposite with its high salaries and below market price for advertising ${ }^{1}$. It is estimated that the newspaper has lost between $\$ 200$ to $\$ 300$ million US dollars since $2007^{2}$ (Ha'aretz, 9.1.2017).

Unlike the majority of free newspapers in the world, Israel Hayom has come to play a very significant role in both Israeli national politics and, we claim, to serve as a disruptive media actor in relation to other, commercial daily newspapers in Israel, the media economy in general and the political system. We thus suggest an alternative model of the free newspaper as disruptive media actor, whose sole purpose, in the case at hand, is to support Israeli PM Benjamin Netanyahu personally (Balmas, et al. 2014) and destabilize the local media landscape, changing it beyond recognition. While this is not the first case of a paper sacrificing profitability for political influence (for example, Canada's National Post), the sustained financial losses, the paper's support of a single politician (rather than a party or political line), together with its impact on the Israeli mediascape make it unique.

Israel Hayom, founded by Sheldon Adelson in 2007 and distributed primarily on public transport and major road junctions has, since 2011, become the most widely read newspaper in Israel $^{3}$. Frequently referred to by the Israeli public as the "Bibiton" (an amalgamation of the nickname of Israel's Prime Minister Benjamin Netanyahu and the Hebrew word for newspaper, "i'iton") the newspaper was

1 http://www.the7eye.org.il/115594 (Hebrew). Accessed 31/5/16

2 http: / / www.haaretz.co.il/ news / education/1.3228188 (Hebrew) Accessed $21 / 3 / 17$

3 http://www.israelhayom.co.il/site/israel. php Approx. 38\% on weekdays and almost $40 \%$ on weekends. Accessed 31/5/16 established by Netanyahu benefactor and financial backer Adelson to serve three primary purposes: first and foremost, to bolster Netanyahu's image among the public. Second, to eliminate via unfair competition Israel's other leading commercial daily newspaper, Yediot Ahronot, which had adopted an anti Netanyahu stance. Third, to destabilize the entire Israeli media economy. Adelson himself has been quoted as saying that "the paper was created to balance the far left agenda of Yediot Ahronot and other Israeli newspapers" ${ }^{4}$ (Ha'aretz, Nov. 2014).

In 2009, and later in 2014, members of the Israeli Knesset, from both the opposition and coalition parties advanced a bill ("Law for the Advancement and Protection of Written Journalism in Israel") directed specifically against Israel Hayom in an attempt to curb its perceived impact. Many viewed the attempt to pass the bill as one of the main reasons for the dissolution of the parliament by Netanyahu and the subsequent 2015 national elections ${ }^{5}$ (Ha'aretz, Dec, 2014). Israel Hayom has been largely successful on all points, bringing into light issues and questions related to political communication, democracy, politics, the media, and the relations between capital, politics, and the press. This is reflected in the language of the proposed bill which notes that "The inability [of the printed press] to compete in a real and fair way in the market on the relative basis of journalistic excellence is due to the distribution of free newspapers" (Israeli Bill 2464/19/P). The leaking of taped conversations between Netanyahu and the publisher of Yediot Ahronot, Arnon Mozes, in January 2017 strengthens this thesis. In the taped conversations, Netanyahu and Mozes are heard bargaining for control of the consensus in Israel, with Netanyahu offering to restrict Israel Hayom (via his relationship with Adelson and as minister of communication) in its competition with Yediot Ahronot in return for favorable coverage of

4 http://www.haaretz.com/israel-news/. premium-1.626053 Accessed 31/5/16

5 http://www.haaretz.co.il/news/politi/. premium-1.2504567 (Hebrew). Accessed $31 / 5 / 16$ 
Netanyahu by Yediot Ahronot (Ha'aretz, $8 / 1 / 2017)$. This picture is further tainted by the fact that Netanyahu also serves as minister of communication, responsible for the regulation of the Israeli mediascape.

We contend that Israel Hayom should be viewed as a "disruptive" media actor in the area of politics and the media in Israel. We do not use the term "disruptive" lightly, or in the positive sense in this case. Adapted from Christensen's (1997/2006) concept of disruptive technology or innovation (a technology, in Christensen's use, that significantly disrupts the traditional order, particularly at an economic level, creating a new reality on the ground), for the purpose of this paper we define as disruptive a media actor that significantly impacts the arenas of politics and the media economy, essentially forcing a change, or changes, in the "rules of the game" at a systemic level, creating a new, monopolistic, media reality. We suggest here that the disruptive media actor is not motivated by profit. It will sacrifice the profitability of a newspaper for wider and deeper political and/or financial goals. The sole purpose of the disruptive media actor is to intentionally disrupt existing media structures and politics. In Christensen's model of disruptive technology, disruption is a byproduct of innovation, not the intended goal. Furthermore, while the Israeli case may in many ways be sui generis, we expect that the model presented here of disruptive media actor may be relevant, based on recent trends, and under certain conditions, to smaller countries in the Balkans, parts of Eastern Europe, and in countries with a similar political economy to that of Israel.

In general, Israel suffers from a highly concentrated media economy with strong cross ownership and segmentation of the majority of the media outlets (Ezrahi, Leshem and Goshen, 2003; Limor and Nossek, 2006; Katz, 1996), including the printed press, television, radio and Internet based news sites (Schejter and Yemini, 2015). This concentration of ownership

$6 \mathrm{http}:$ / / www.haaretz.com / is raelnews/1.763649 (English). Accessed $30 / 3 / 2017$ and cross ownership is highly problematic in a democratic regime in terms of media pluralism and the public sphere (Habermas, 1991). As in many developed democracies, printed news has suffered the most. In Europe, quality papers have moved to a tabloid format or have been trying to raise money from investors. The Israeli printed press has faced similar difficulties; with only two mainstream daily newspapers left: Yediot Ahronot and Ha'aretz. In 2014 Adelson bought Ma'ariv's online presence, NRG, as well as the leading niche right wing newspaper Makor Rishon. In addition to these activities, Adelson is developing yet another mobile online presence, 360.co.il, again drawing on Israel Hayom for content.

The purchase of the NRG website is an important indication of Adelson's intention to become a dominant player in the popular web based news industry in Israel. The decision to buy a well established site and not to use the existing Israel $\mathrm{Ha}$ yom website or domain as a platform for expansion, raises serious questions about the purpose of the acquisition. The decision to obfuscate the working relationship between Israel Hayom and the NRG and News 360 websites, considering that web based news, as most news outlets in Israel, is already very concentrated, and suffers from cross ownership is problematic to say the least. (Schejter and Yemini, 2015). In this case there are three distinct online media entities, all drawing content from Israel Hayom.

It would seem that the use multiple web based platforms by Adelson for essentially the same content is an attempt to disguise the relationship between the different sites. A possible explanation may be found in the fact that the Israeli public is well aware of the relationship between Netanyahu and Israel Hayom, and multiple platforms with similar content shared across social networks serves to mask the provenance of the content, making them more effective as pro Netanyahu platforms. 


\section{Israeli media landscape}

The Hebrew language press in Israel predates the establishment of the state in 1948. Hebrew newspapers were seen as an integral part in the revival and modernization of the Hebrew language, with the first such paper established in Jerusalem in 1863. Ha'aretz (Israel's paper of record) was established in 1918. Yediot Ahronot, formerly the most popular paper in Israel, was established in 1936. Political movements and parties also had their own newspapers which were widely read. Today, there are only two commercial dailies remaining: Yediot Ahronot and Ha'aretz, both struggling. There are also three daily financial newspapers, and one other free newspaper, a cannibalization of the remains of Ma'ariv under the ownership of the Jerusalem Post, a very thin Ma'ariv Haboker, (Morning Ma'ariv) with insignificant distribution.

Beyond the printed press, Israel has a fairly saturated media landscape, with 1 public TV station and 2 commercial TV stations, cable and satellite services, two public radio networks and 14 regional radio stations, which tend to encourage segmentation (Katz, 1996) rather than national integration. This is matched with a significant and popular online presence of media (Gilboa, 2008). And while the landscape is rather rich, Israel is also known for its high levels of media concentration and cross ownership of media and infrastructure (content and platform), in spite of attempts at anti trust and anti monopoly actions (Schejter and Yemini, 2015). This can have harsh consequences for any democracy, as noted by Baker $(2002,2006)$ and McChesney $(1995,2015)$. As in other countries, advertising revenue has migrated from the printed press to online media. Essentially, much of the media landscape in Israel is controlled by five family based local media conglomerates (Schejter and Yemini, 2015). This is matched by increasing levels of politicization of public broadcasts, and political interventions and pressures directed against TV channels, media outlets, and journalists (Caspi, 2008). Exacerbating these structural lacunae is the fact the current PM, Benjamin Netanyahu, also serves as minister of communication, responsible for regulation of both media and infrastructure. The result, at least in terms of print and broadcast media, is nothing short of a crisis.

In addition, one must take into account a closely related phenomenon: the impact of the personalization of politics in general (McNair 2011, McAllister 2007, Bennett 2012, Van Aelst et al., 2012) and in the Israeli case, the deep personalization of politics, at the expense of both party and ideology (Rahat and Sheafer, 2007). This has been reflected very strongly in the election campaigns of the last decade (ibid.). On the part of Israel Hayom, this personalization is reflected in its support of Netanyahu specifically - not his $L i$ kud party, and not necessarily right wing politics, as differing views are expressed within its editorial pages. Content analysis shows that the news content itself tends to support the general Israeli consensus, more or less in line with main stream media outlets, with a center right slant, yet is consistent in its very positive portrayal of Netanyahu, his wife, his family and his policies (Balint, 2015).

In spite of the crisis and the deficits noted above, the printed press in Israel remains a central and important source for news and the generation of public discourse. The printed press remains one of the primary gate keepers and mediators of the news, alongside television and radio. The entry of a new and crushing actor into this saturated, crumbling arena would thus seem strange if the purpose of the newspaper was to generate profit, as there is little left of the pie - yet as we will see in the next section, the intentions of Israel Hayom go far beyond mere profit, having actively sought and succeeded to impact both the media landscape and the political system at various levels.

\section{Israel Hayom}

Israel Hayom, a free daily paper with a circulation of 400,000 copies on the weekend $(275,000$ weekdays) in a country of 8 mil- 
lion citizens stands firmly at the nexus of issues related to democracy, the media, the personalization of politics, media concentration and cross ownership as well as the political economy of the media in Israel. While one could easily conduct a political economy based critique and analysis of $I s$ rael Hayom, providing insight into capital, the media and politics in Israel, we propose viewing the paper in a different light entirely, that of disruptive media actor.

Israel Hayom was founded in 2007 by the American billionaire and Netanyahu benefactor, Sheldon Adelson. It is one of the first free newspapers in Israel, and by far the most successful. The paper enjoys the highest circulation of a newspaper in Israel, commercial or otherwise, with close to $40 \%$ readership on weekdays (actual readership is a bit higher - the paper is often left on the bus for future passengers, thus one paper is read by many passengers over the course of the day). Readership on public transportation are primarily young soldiers, setting future reading patterns for this population. As Lamour (2016) notes, "circulation strategies within space are certainly central to an explanation of the success of this medium". The other free newspaper, Ma'ariv Haboker, is distributed in a similar fashion, but has an insignificant distribution.

Adelson also owns a newspaper in Las Vegas run at a loss, the Las Vegas Review - yet in this case both the ownership and lack of profit are understandable - Adelson has many business interests in Las Vegas, and owning a major newspaper in a city where one operates commercially is understandable, even if the newspaper is run at a loss. In the case of Israel Hayom, Adelson is not involved or invested in any significant way in the Israeli economy beyond his involvement with the press ${ }^{7}$, suggesting an alternative model of the free newspaper as a disruptive media actor, in this case being used as a tactical media

7 Map of the ownership and cross ownership of media organizations in Israel, produced by the $7^{\text {th }}$ Eye, a media watchdog publication, published by the Israel Democracy Institute (Hebrew). http://www.the7eye.org.il/50534 Accessed 31/5/16 weapon, whose sole purpose is to support Netanyahu and destabilize the local media landscape, changing it significantly.

\section{Israel Hayom as disruptive media actor}

As noted above, we suggest applying the model of disruptive media actor to the free newspaper Israel Hayom, due to its significant impact at a systemic level, essentially forcing the closure of a veteran commercial newspaper (Ma'ariv) while destabilizing the media landscape on the whole with the introduction of an owner-subsidized business model. Since its inception in 2007, it has been estimated that the newspaper loses on average $\$ 2.5$ million US dollars for each month of operation, or \$30 million US per year, and has been actively and openly seeking the weakening and destruction of existing media structures $^{8}$, in this case, Yediot Ahronot. In addition to these losses, the paper charges only half of the market rate for advertisement $^{9}$, raising serious questions as to its financial goals and its business model. We thus contend that the disruptive media actor operates to pursue a goal that has little to do with profit. The goal is disruption itself. It will sacrifice the profitability of a newspaper for wider and deeper political and/or financial goals - in the Israeli case, the strengthening of Netanyahu's public image, entrenching him as the only viable political candidate. What was initially conjecture was made clear with the release of the Netanyahu-Mozes tapes noted earlier.

We thus propose an even wider view, beyond that of the destabilization of the media landscape, and suggest considering the impact of such an actor at the social and political levels. Israel Hayom contributes to the devolving political discourse in Israel by blindly and uncritically supporting Netanyahu, it damages the public sphere by monopolizing printed media and attempting to dominate online media,

8 http://www.the7eye.org.il/115594 (Hebrew). Accessed 31/5/16.

9 http://www.the7eye.org.il/102339 (Hebrew). Accessed 31/5/16 
serves to damage liberal values related to the press and democracy, and serves as a platform for political struggles and the de-legitimization of traditional gatekeepers in Israeli politics such as the supreme court.

On the $17^{\text {th }}$ of March, 2015 general elections were held in Israel - in which Netanyahu was once again successful in forming a ruling coalition. The previous parliament was dissolved two years early by Netanyahu for one primary reason: to derail attempts to legislate a law directed against the Israel Hayom newspaper - a law that would essentially force its closure. During the coalition formation process following the 2015 elections, it was widely reported that one of the conditions posed by Netanyahu for joining the coalition was acceptance by potential partners of a clause that would give the communication minister (a position eventually held by Netanyahu himself) the power to decide which media laws and reforms would be advanced and which would be buried ${ }^{10}$ (Ha'aretz, 29.4.2015). Similar language was later used in the signed coalition agreements ${ }^{11}$, essentially leaving Netanyahu total control of the regulation of the media, telecommunications and the Internet in Israel as minister of communication.

Furthermore, considering the fact that the paper has maintained a consistently pro Netanyahu stance, while there are stringent restrictions on contributions to politicians under the election laws, a newspaper like Israel Hayom, whose only real purpose as we have seen would seem to be to support Netanyahu, is a sophisticated way to bypass fundraising restrictions. Indeed, prior to the 2015 elections, an appeal was made to Central Election Committee to prevent the distribution of Israel Hayom close to elections because the newspaper should be considered as forbidden party propaganda. The appeal

$10 \mathrm{http}: / / \mathrm{www} \cdot$ haaretz.com/israel-news/. premium-1.654009 Accessed 31/5/16

11 Current coalition agreements with all parties, including the relevant clause (Hebrew): http://main.knesset.gov.il/mk/government/ Pages/CoalitionAgreements.aspx Accessed $31 / 5 / 16$ was supported by a report produced by media researcher Dr. Anat Balint from Tel Aviv University. Her report concluded "theoretically and empirically that Israel Hayom has a strong positive bias towards Netanyahu, his family and his immediate circles, attempting to whitewash any public or media criticism"12 (Balint, 2015). The Committee denied the appeal (Globes, 11.2.2015). In addition to this, the 2016 Freedom House report on press freedom lowered Israel's rank from free to partially free, primarily due to "the growing impact of Israel Hayom, whose owner-subsidized business model endangered the stability of other media outlets, and the unchecked expansion of paid content - some of it government funded - whose nature was not clearly identified to the public ${ }^{13}$." The report also notes that "Economic pressures have undermined the sustainability of key outlets in recent years, threatening longterm media pluralism", in direct relation to Israel Hayom (ibid.). To this one may add the recent expansion of web based news outlets by Adelson.

The paper itself brushes away any criticism - whether in regard to its editorial stance and slant, the close relationship between the managing editor and Netanyahu, its blatant support of Netanyahu, or the logic behind its business model as either political attacks or as slander of competing newspapers.

The dissolution of the parliament by Netanyahu, less than two years after its formation, together with Netanyahu's insistence on the above mentioned clause during subsequent coalition negotiations, the taped conversations between PM Netanyahu and Mozes, the publisher of Yediot Ahronot, all serve as indicators of the importance of Israel Hayom, and when taken together with other aspects, serves to strengthen our view of Israel Hayom as a disruptive media actor.

12 http: / / www.globes.co.il/ news / article. aspx?did=1001008640 (Hebrew). The appeal, which is presented here, also links to the full report (Hebrew) by Balint. Accessed 31/5/16

13 https: / freedomhouse.org/report/freedompress/2016/israel Accessed 31/5/16 


\section{Conclusion}

Israel Hayom is an excellent, if sui generis example of the impact that a free, owner-subsidized, partisan newspaper can have, even in an era where both commercial and free press are struggling to survive. As we have shown, the newspaper has impacted many levels of Israeli society - from the heavily concentrated and cross owned media landscape, to the very stability of a ruling coalition - to the detriment of the media, the public sphere and liberal democratic values. All this, in the service of Prime Minister Benjamin Netanyahu's political career (now the longest reigning Prime Minister in Israeli history), his family and his cohorts. As we have noted, the business model of the paper lacks any coherent, financial logic beyond that of consistently losing substantial capital on a monthly basis.

A disruptive media actor significantly and intentionally impacts the arenas of politics and the media economy, forcing systemic changes in the "rules of the game", creating a new, monopolistic media reality. The disruptive media actor is not motivated by profit or financial gain, rather it is focused on a larger and singular goal - the disruption of both the political system and the existing media economy. Disruption is the goal, not a byproduct of the introduction of a new model. As we have shown, Israel Hayom has dedicated significant resources to bolstering Benjamin Netanyahu's public image, his political career and his continued reign as prime minister, first with a free newspaper and now expanded to online media sites. In this sense Israel Hayom can be viewed as a tactical media weapon. Attempts by legislators on both the left and right of the political spectrum to restrain the newspaper were met by Netanyahu with the dissolution of a stable government coalition and new elections in which Netanyahu was re-elected.

We suggest that future comparisons (should they arise) be based on Hallin and Mancini's (2004) framework, with four primary dimensions for comparison: media systems; political parallelism; degree of professionalization; and the role of the state in relation to the media system. We find these dimensions useful for identification and comparison, in particular due to the presence of the political context, which we view as crucial for the understanding of the Israeli case, or any other future case for that matter.

Further cases are necessary of course in order to qualify and demonstrate the efficacy of the disruptive media actor model - yet we are certain that similar cases will present themselves in the future - most likely in the smaller Eastern European and Balkan states, and in countries close to the polarized pluralist model (a dual or multi party system with high polarization) suggested by Hallin and Mancini (2004), correlating for smaller population size.

\section{References}

Balmas, M., Rahat, G., Sheafer, T., \& Shenhav, S. R. (2014). Two routes to personalized politics Centralized and decentralized personalization. Party Politics, 20(1), 37-51.

Bennett, W. L. (2012). The personalization of politics political identity, social media, and changing patterns of participation. The ANNALS of the American Academy of Political and Social Science, 644(1), 20-39.

Baker, C. E. (2006). Media concentration and democracy: Why ownership matters. Cambridge University Press.

Baker, C. E. (2002). Media concentration: Giving up on democracy. Fla. L. Rev., 54, 839.

Bakker, P. (2013). The life cycle of a free newspaper business model in newspaper-rich markets. Journalistica-Tidsskrift for forskning i journalistik, 2013(1).

Balint, A. (2015). Israel Hayom as forbidden election propaganda. Report submitted to the Central Election Committee, Israel. (Hebrew).

Christensen, C. M. (2006). The ongoing process of building a theory of disruption. Journal of Product innovation management, 23(1), 39-55.

Christensen, C. M. (1997). The innovator's dilemma. Harvard Business School Press, Cambridge, MA. 
Campus, D. (2010). Mediatization and personalization of politics in Italy and France: The cases of Berlusconi and Sarkozy. The International Journal of Press/Politics, 15(2), 219-235.

Caspi, D. (2008). On politicization of the Israeli Broadcasting Authority. In M. Neiger, M. Blondheim, \& T. Liebes (Eds.), Telling news stories - Perspectives on media discourse in Israel (pp. 125-165) [in Hebrew]. Jerusalem, Israel: Magnes \& Smart Institute, Hebrew University.

Ezrahi, Y., Goshen, Z., \& Leshem, S. (2003). Cross ownership: Control and competition in the Israeli media - Economic and legal aspects and their impact on the Israeli democracy [in Hebrew]. Jerusalem, Israel: The Israel Democracy Institute.

Gilboa, E. (2008). The evolution of Israeli media. Middle East Review of International Affairs, 12, 88-101.

Habermas, J. (1991). The structural transformation of the public sphere: An inquiry into a category of bourgeois society. MIT press.

Hallin, D. C. \& Mancini, P. (2004). Comparing media systems: Three models of media and politics. Cambridge University Press.

Katz, E. (1996). And deliver us from segmentation. Annals of the American Academy of Political and Social Science, 546, 22-33.

Lamour, C. (2016). Free Dailies in the European Cross-Border Metropolis: The State-Based Economic Deals. International Journal of Communication, 10, 20.

Limor, Y. (2003). Mass media in Israel. In E. Ya'ar \& Z. Shavit (Eds.), Trends in Israeli society [in Hebrew] (pp. 1017-1103). Tel Aviv, Israel: The Open University of Israel.

Limor, Y. \& Nossek, H. (2006). The Military and the Media in the Twenty-First Century: Towards a New Model of Relations. Israel Affairs, 12(3), 484-510.

McAllister, I. (2007). The personalization of politics. The Oxford handbook of political behavior, 571-588.

McChesney, R. W. (2015). Rich media, poor democracy: Communication politics in dubious times. New Press, The.

McChesney, R. W. (1995). Telecommunications, mass media, and democracy. Oxford University Press.

McNair, B. (2011). An introduction to political communication. Taylor \& Francis.
Rahat, G. \& Sheafer, T. (2007). The personalization (s) of politics: Israel, 1949-2003. Political Communication, 24(1), 65-80.

Schejter, A. M. \& Yemini, M. (2015). "A time to scatter stones and a time to gather them": Electronic media industries concentration trends in Israel 1984-2013. Telecommunications Policy, 39(2), 112-126.

Van Aelst, P., Sheafer, T., \& Stanyer, J. (2012). The personalization of mediated political communication: A review of concepts, operationalizations and key findings. Journalism, 13(2), 203-220. 